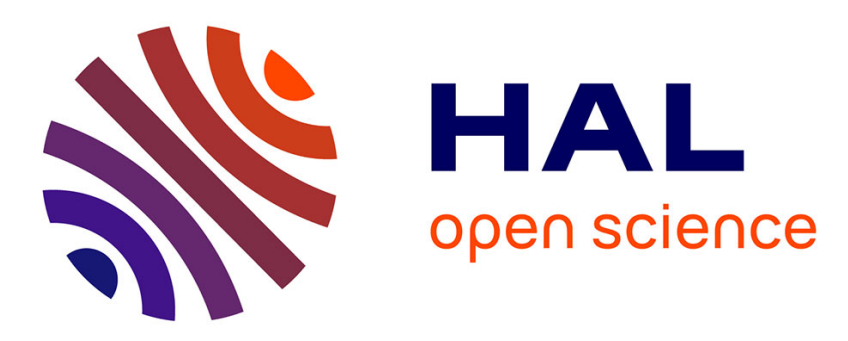

\title{
Bargained Equality: The Strengths and Weaknesses of Workplace Gender Equality Agreements and Plans in France
}

Susan Milner, Hélène Demilly, Sophie Pochic

\section{> To cite this version:}

Susan Milner, Hélène Demilly, Sophie Pochic. Bargained Equality: The Strengths and Weaknesses of Workplace Gender Equality Agreements and Plans in France. British Journal of Industrial Relations, 2019, 57 (2), pp.275-301. 10.1111/bjir.12437 . hal-01962165

\section{HAL Id: hal-01962165 https://hal.science/hal-01962165}

Submitted on 20 Dec 2018

HAL is a multi-disciplinary open access archive for the deposit and dissemination of scientific research documents, whether they are published or not. The documents may come from teaching and research institutions in France or abroad, or from public or private research centers.
L'archive ouverte pluridisciplinaire HAL, est destinée au dépôt et à la diffusion de documents scientifiques de niveau recherche, publiés ou non, émanant des établissements d'enseignement et de recherche français ou étrangers, des laboratoires publics ou privés. 


\title{
Bargained Equality: The Strengths and Weaknesses of Workplace Gender Equality Agreements and Plans in France
}

\author{
Susan Milner (iD, Hélène Demilly and Sophie Pochic
}

\begin{abstract}
'Bargained equality' reflects wider characteristics of French employment relations whereby state-driven collective bargaining is a major mode of regulation but is based on weak workplace bargaining cultures outside the largest firms. This article focuses on duties on French employers to bargain on gender equality. It presents findings of a project evaluating workplace agreements and plans on gender equality, based on a sample of 186 agreements submitted in 2014-2015, in 10 sectors, and in-depth interviews in 20 companies. Despite a rise in formal compliance due to stronger enforcement since 2012, our analysis shows that most companies submitting plans or agreements do not systematically address quantitative measurement of pay or other gender gaps. As well as sectoral differences, the analysis also identifies 'generational effects': processes of change which occur as collective agreements expire and are replaced are dependent on local dynamics of bargaining. Based on this analysis, we argue that attention should be paid to the resources available to local bargaining actors, in order to promote an equality agenda.
\end{abstract}

\section{Introduction}

In many countries, progress on the gender pay gap has been slow, reflecting macro-institutional and micro-level tensions in the contested employment relationship (Rubery and Smith 2015). In the British case, for example, awareness of the limits of a litigation-based approach led in the early 2000s to new regulatory approaches, although initiatives in the Equality Act 2010 have only partly been enacted (Deakin et al. 2015). Most scholars and activists 
agree that basic information about the gender breakdown of wages and other aspects of working life is a necessary first step in addressing any inequalities (see, e.g., Bohnet 2016), but they may disagree about how to interpret that information and what to do about it. In the United States, where the business rhetoric of equality and diversity originated, there is evidence that a targetdriven approach is not only ineffective but can create backlash from managers (see Dobbin and Kalev 2016). Experts are, however, divided on whether the best approach is stronger legal duties (Chicha 2006) or more integrated, bottom-up discursive interventions in the workplace, coupled with leadership champions and mentoring (Dobbin and Kalev 2016). Others suggest that the best approach may be through reflexive legislation aimed at encouraging change in employer behaviour (Conley and Page 2018). In fact, a wide variety of practices exist under the broad heading of equality and diversity, as employers seek to integrate such initiatives into their own organizational practice and culture (Edelman et al. 2001; Qin et al. 2014).

Collective bargaining constitutes a significant part of the regulatory toolkit for tackling gender-based inequalities in pay and working conditions, as it is responsive to local needs and resources (Dickens 2000; Kirton 2011) and inhibits the widening of pay differentials (Grimshaw et al. 2014), particularly where coordination between different levels of bargaining is strong (Berg and Piszczek 2014; Blau 2012; Williamson and Baird 2014). However, the institutional actors in collective bargaining have varying degrees of commitment to tackling gender inequalities (Dickens 2000). Moreover, in the context of economic downturn, bargaining has been weakened as a regulatory mechanism (Milner and Gregory 2014; Bosch 2015; Brochard and Letablier 2017; Voss et al. 2015).

The tension between transformative potential and regulatory capacity is starkly illustrated in the French case, which has been described as 'statemanaged bargaining' (Mias et al. 2016) or 'bargained public policy' (Groux 2005). Here, collective bargaining has become a significant tool of state policy including gender equality in the workplace. The role of the state, which intervenes using a mixture of sanctions (financial penalties) and incentives (such as tax relief), is ambiguous: it seeks to strengthen and extend the scope of bargaining as an autonomous sphere of regulation, but also steers and frames it (Naboulet 2011; see also Baccaro and Howell 2017). Bargaining is shaped by the duties imposed on employers by the state which increasingly make the company rather than the sector the locus of negotiation (Mias 2014; Mias et al. 2016; Rehfeldt and Vincent 2018; see also Baccaro and Howell 2017: 92-3). Yet questions have been raised about the real impact of state-managed bargaining on workplace practices, both quantitatively and qualitatively (Naboulet 2011).

Quantitatively, the number of agreements has increased, particularly at workplace and company levels, but significant gaps remain in coverage (with employees in smaller companies and in low-pay sectors largely left outside the scope of bargaining). Qualitatively, state-managed bargaining can encourage employers to invest in equality bargaining in the absence of other strong pressures for action, and to create dynamics of negotiation where they did 
FIGURE 1

Unadjusted Gender Wage Gap (\%), France, 2000-2013.

[Colour figure can be viewed at wileyonlinelibrary.com]

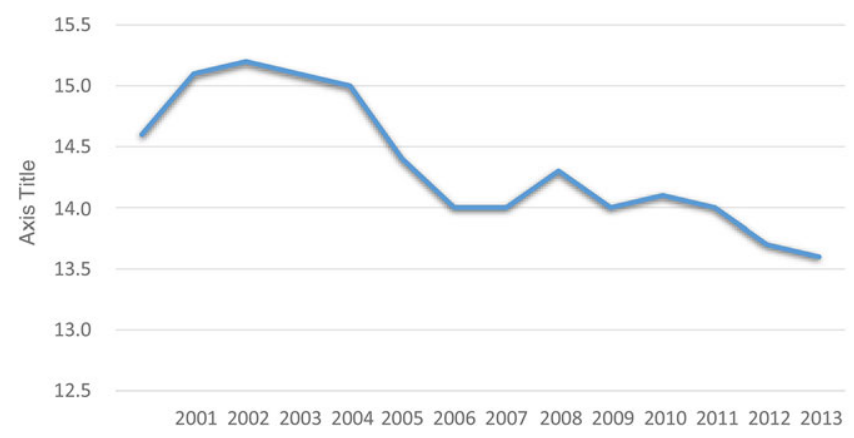

Note: Figures show female pay as percentage (\%) of median gross male pay. Source: OECD (2016).

not previously exist or were only weakly present. However, for state-driven bargaining more generally, it is observed that employers are able to direct local bargaining processes to escape legislative control (Giraud and Ponge 2016). Even where they are formally compliant with obligations to bargain they may be delivering weak agreements which provide little in the way of concrete actions or additional protections beyond legal minima.

The efficacy of state-managed bargaining depends on favourable conditions: strong and committed interlocutors, a culture of dialogue and negotiation and good economic climate (Naboulet 2011). All three conditions are problematic in France. First, the weakness of trade unions, with density at around 11 per cent (9 per cent in the private sector; see Pignoni 2016, 2017), is long-standing and well documented (see also Gumbrell-McCormick and Hyman 2015). Unions are much stronger at sectoral than at workplace level. Second, the architecture of bargaining is recognized to be weak, with poor articulation between levels (Bechter and Brandl 2014: 35; Combrexelle 2015). Third, bargaining and reforms to the architecture of bargaining are taking place in a tough economic climate.

Bargaining on workplace gender equality illustrates these ambiguities of 'state-managed bargaining' (Naboulet 2011). France has equal pay legislation going back to ratification of ILO Convention 100 (1951) in 1953, and its aggregate unadjusted gender pay gap is consistently lower than the EU average. However, the persistence of the gender pay gap has become a concern for governments of both right and left (see Figure 1). In order to encourage actors of workplace regulation - principally employers and trade unions - to give priority to gender equality, the main plank of government activism since 1983 (when the 'Roudy' law included transposition of the EC's equal pay legislation) has been the promotion of sectoral and workplace bargaining, with at best mixed results (Laufer 2014). The development of increasingly strong employer duties and complex compliance requirements 
has thus created a distinctive model of 'bargained equality'. Beyond the question of legal compliance, what impact does 'bargained equality' have at the level of the workplace?

This article seeks to contribute to these debates about the robustness of collective bargaining as a means of social regulation, and about the relationship between legal instruments and management practices in generating effective policies to reduce gender disparities at work. We first outline the development of 'bargained equality' duties and show how they have become both stronger and more complex, with the introduction of financial penalties for non-compliance in 2012. We then outline three main hypotheses about the impact of these changes on the efficacy of 'bargained equality', understanding efficacy or substantive compliance to mean the extent to which agreements and plans address the specific areas prescribed by the law, including the quality of the diagnostic data provided, and whether concrete, measurable actions are identified with quantitative indicators under each heading to enable monitoring and follow-up activity (see also Pépin et al. 2008). The article identifies the main actions outlined in a sample of texts lodged in 2014-2015 with the Ministry of Labour, and analyses these actions in relation to the discursive drivers of change, structural factors such as sector of activity, the actors involved and the resources available to them. The concluding section discusses the findings in relation to the three hypotheses about the impact of employer duties, and reflects on the wider significance of France's model of 'bargained equality' at a time of economic and restructuring and policy change.

\section{2. 'Bargained equality': conceptualizing the extension of employer duties in France}

The introduction of employer duties in the 1983 Roudy law was followed by four broad waves of laws (outlined in Table 1), tightening legal requirements and placing them within the scope of collective bargaining. These duties were usually introduced in the context of wider laws framing workplace gender equality (including measures to address horizontal segregation and work-life balance, and later also gender stereotyping), apart from the 2010 measure which was adopted within a law on pensions reform. In recent years, there has also been concern with representation of women in decision making, with notably the adoption of the 2011 Copé-Zimmerman law introducing quotas for women on boards (40 per cent by 2017) (see Bender et al. 2010; Bereni 2015; Smith et al. 2012). Pay equity is thus one aspect of a wider view of equality also including workforce composition and working conditions.

Together these laws mark a shift in legislative approach from protection of working women to the principle of full equality at work, based on three main instruments: employers' duty to integrate equality into regular collective bargaining; the deployment of standard quantitative indicators to inform workplace equality initiatives and reporting; and the use by the state of 
TABLE 1

Chronology of the Development of 'Negotiated Equality' in France

\begin{tabular}{lc}
\hline (Wave) Date & Legal requirements \\
\hline 1983 & $\begin{array}{c}\text { Roudy law: duty to produce annual } \\
\text { monitoring report; applicable to }\end{array}$ \\
& companies with 50+ employees \\
(1) 2001 & $\begin{array}{l}\text { Génisson law: duty to bargain on } \\
\text { equality (applicable to } \\
\end{array}$ \\
& companies with 50+ employees)
\end{tabular}

(2) 2006

(3) 2010

2012

(4) 2014

2015-2016
Ameline law: deadline (31

December, 2010) for companies to 'close the gender pay gap' through collective bargaining and reporting

Pension reform law and decree introduces financial penalties for non-compliant companies, that is those without equality agreement or employer's plan

Sauvadet law: analogous equality duties for public-sector organizations

Vallaud-Belkacem law on 'real equality': merges equal pay bargaining and equality bargaining; introduces equal value evaluations, to be revised every five years at branch and company levels; equality duty for candidates to public market; reform of parental leave (shared)

Rebsamen law: merges equality bargaining with quality of work bargaining and integrates the RSC in a single HR legal database
Comments

RSC (Rapport de situation comparée): six specific areas of action

Annual equality reports as a basis for bargaining (three-year agreements): standard format of RSC for large companies (300+ employees), with more than 20 indicators, but based on 'same work' (not 'comparable worth')

Introduces new indicator on work-life balance in RSC and compensatory wage adjustment for maternity leave (mean wage increase during leave period)

First non-compliance notices issued in 2013. Firms can be fined up to $1 \%$ of total wage bill

Procedural compliance: two (or three) domains of action minimum, quantitative indicators and targets for monitoring change

Law distinguishes between large companies (300+ employees) with obligation to negotiate targets on four areas minimum; those with 50-300 have duty to negotiate on 3 areas minimum

Public procurement linked to compliance

New gendered indicators on health and safety, and career advancement, in HR database ${ }^{\mathrm{a}}$

aSince July 2016, due to feminist organizations' mobilization, the HR legal database must include the same list of gendered indicators for large and small companies.

financial sanctions for non-compliance (Miné 2016). A distinctive feature is the reliance on collective bargaining: where trade unions are not present (or in cases where bargaining fails to result in agreement) companies must submit a 'unilateral' plan which should also be communicated to any representative bodies such as works councils or elected workplace delegates. This means that effectively the law covers all private-sector companies with 50 or more employees, to which wider collective bargaining duties and rules on elected workplace representation bodies apply. 
TABLE 2

Collective Agreements on Gender Equality since 2007, Sectoral and Company Level

\begin{tabular}{|c|c|c|c|c|}
\hline \multirow[b]{2}{*}{ Year } & \multicolumn{2}{|c|}{ Sectoral level } & \multicolumn{2}{|c|}{ Company level } \\
\hline & $\begin{array}{c}\text { Number on } \\
\text { gender equality }\end{array}$ & $\begin{array}{l}\text { Number including } \\
\text { gender equality with } \\
\text { other issues } \\
\text { (Percentage of total) }\end{array}$ & $\begin{array}{l}\text { Number of } \\
\text { agreements on } \\
\text { gender equality }\end{array}$ & $\begin{array}{l}\text { Percentage of } \\
\text { total signed by } \\
\text { trade unions }\end{array}$ \\
\hline 2007 & 9 & $33(3.2)$ & 1,214 & 4.5 \\
\hline 2008 & 19 & $53(4.5)$ & 1,723 & 5 \\
\hline 2009 & 35 & $110(9.5)$ & 2,522 & 6.5 \\
\hline 2010 & 37 & $149(12.8)$ & 2,124 & 9 \\
\hline 2011 & 27 & 167 (13.5) & 6,409 & 16 \\
\hline 2012 & 19 & $183(14.5)$ & 7,135 & 17 \\
\hline 2013 & 9 & $122(12.1)$ & 3,501 & 11 \\
\hline 2014 & 6 & $140(14.3)$ & 2,909 & 9 \\
\hline
\end{tabular}

Source: Ministère du Travail (2015) (sectoral level for 2007-2014; company level for 2014); Ministère du Travail (2014) (company level for 2011-2014); Ministère du Travail (2014) (company level for 2007-2010).

Since the 2010 law, which announced penalties for companies that had not adopted plans or agreements by 2012, 103 companies have been fined for non-compliance, amounting to on average 0.5 per cent of their wage bill. ${ }^{1}$ Smaller companies are disproportionately represented among non-compliant firms with neither equality plan nor agreement, as are certain sectors namely (private) health, retail and manufacturing. Formal compliance increased after formal warnings were issued: 2,157 since 2013. The number of collective agreements rose sharply in response to the tightened requirements, as did the number of 'unilateral' equality plans. Thus, the number of sectoral agreements increased significantly in 2010 and has continued at around the same level since then, ${ }^{2}$ although the number dealing solely with gender equality has declined and was always small (see Table 2). The number of company level agreements similarly rose to a peak in 2012, showing the effect of the 2010 law introducing financial penalties, but has dropped since then, nevertheless remaining at a level twice as high as in 2007. Overall, 39 per cent of companies covered by the law had an agreement or plan in place in January 2016, up from 27 per cent in January 2014.

Studies of these agreements have identified several trends suggesting changing dynamics of company-level equality bargaining and its relationship with the law. First, in line with the broader pattern of collective bargaining (Amossé et al. 2008), the early agreements on gender equality (following the Génisson law) occurred mainly in large companies in manufacturing and finance (Laufer and Silvera 2005). More recently, although coverage among larger companies remains higher, at 84 per cent for very big firms (1,000+ employees), 69 per cent for medium- to large-sized firms (300-999) and 34 per cent for small firms (50-299), ${ }^{3}$ small- to medium-sized companies are increasingly engaged in gender equality bargaining and auditing (Grésy et al. 2014). 
Second, the capacity of actors on the ground to analyse gender equalities within the workplace, and to address them, has increased overall but varies considerably between and within sectors. A number of weaknesses and gaps have been identified in the earlier agreements and plans. The highly technical nature of equalities auditing means that a good deal of training and experience is necessary (Grésy et al. 2014). The increasingly focused requirements for reporting, which should form the basis for bargaining and also be communicated to works councils, are intended to address gaps in the pay equity system around job evaluation and measurement of equal value (Chicha 2006; Laufer 2014; Lemière and Silvera 2010). In principle, they set out a precise format for detailed statistical reporting and for actions to address any disparities identified. The compliance machinery is designed to verify procedural compliance, that is, reporting in key specified areas linked to statistical findings, in the form (in companies with 300 employees or more) of a Rapport de situation comparée (RSC) which is a detailed gender audit with specific gendered breakdowns of workforce composition by occupation, type of contract, working time arrangements, family-related and other types of leave, access to training, working conditions, pay scales and bonuses and average time between promotions (Grésy et al. 2014). ${ }^{4}$

However, this in turn has raised the knowledge bar for all bargaining parties. Access to statistical knowledge and expertise - in particular the ability to identify and analyse the causes of gender pay gaps - empowers actors on the ground (Bruno et al. 2014). Conversely, if expertise is difficult to attain, there is a risk of inertia or of 'empty' texts designed purely to provide formal or 'lip-service' compliance (Milner and Gregory 2014). Similarly, if the required information and action on pay systems and classifications proves difficult to attain or put in place (requiring significant organizational buyin at all levels), the complexity of the legal requirements allows companies to focus on relatively cost-neutral measures which are unlikely to reduce inequalities (Laufer 2014). Thus, the themes of equal opportunity in training and recruitment have been found to be more frequently evoked in 'empty' or purely formal documents, which in turn are more likely to be unilateral plans than agreements (Dunez and Graff 2013; Munoz 2013).

These risks could potentially be mitigated by supportive measures, first regarding the balance of sanctions and incentives in policy design, second in the form of accompanying technical support and training. In the case of equality bargaining, at national level, guides and toolkits have been produced, including a detailed explanation of how to analyse pay structures and workforce gender composition and identify gender disparities (Grésy and Becker 2017). A national network of experts on job evaluation and working conditions (ANACT) provides free, bespoke expertise. Fifteen of the 22 regional authorities have also signed contracts with the state to provide material and financial support to companies on gender equality, with a particular focus on smaller companies. Other potential resources to support bargaining include private consultants, a growing number of which specialize 
in gender pay auditing and other aspects of equality such as recruitment and promotion.

The tightening of legal duties on employers with the introduction of financial penalties for non-compliance, the more specific prescriptive template for reporting, and the provision of support services in the form of external expertise, would lead us to expect not just a rise in formal compliance (i.e. quantitatively, the number of companies lodging agreements and plans) but also improved efficacy of outcomes, that is, qualitatively, a high degree of substantive compliance with detailed diagnosis of gender gaps, specific actions to address them, and indicators to allow monitoring and follow-up. However, the 'empty shell' hypothesis would suggest that formal compliance may not be accompanied by substantive compliance as companies seek mainly to avoid penalties. Alternatively, based on existing literature on collective bargaining and on sectoral configurations of gender inequalities (Peetz 2017), we would expect to find an increase in substantive compliance but a high degree of variation between and within sectors.

Collective bargaining is strongly influenced by existing sectoral (both regulatory and compositional) factors (see Greulich et al. 2013). In the case of gender equality, French law requires sectoral bargaining to influence local bargaining in two main ways: first, sectoral bargaining establishes pay scales and classifications which form the basis for company wage bargaining; second, regarding gender equality, employers and trade unions at sectoral level are encouraged to agree on joint initiatives to identify key issues for the sector, disseminate information guides and toolkits and establish a database of agreements which can be used as a resource by local negotiating teams. However, annual government reviews of collective bargaining highlight significant differences between sectors which have relatively strong bargaining practices and those which are fragmented into many small sub-sectoral branches, or where employers' associations are weakly engaged in bargaining (Combrexelle 2015). This regulatory variation reflects structural-economic and social characteristics of the sector. While we might expect employers in general to see gender equality as an important but not a priority area (Mias 2014), structural factors make employers in some sectors more disposed towards collective bargaining than in others, and workforce characteristics also influence awareness of and attitudes towards gender equality initiatives.

Company size is a well-documented factor of employer propensity to engage in bargaining, in France as elsewhere (Brown 2009). We also expect existing local bargaining practices and cultures to influence outcomes, as some organizations enter their fourth or fifth iteration of early agreements, with all the stock of knowledge and learning this is likely to engender. However, such processes are not linear; gender equality like other areas of employment relations is the site of intense conflict (Chappe and Pochic 2018). In our study, we seek to identify 'generational effects' in the most recent wave of collective agreements. We expect to see more evidence of such effects in agreements more than plans, since unions have a stake in monitoring actions after the signature of an agreed text. However, we also expect generational effects to 
vary, depending on the mobilization capacity and resources of local actors. Dynamics of collective bargaining — an intrinsically conflictual process - are central to the type and nature of equality agreement (Dunez and Graff 2013) and to the process of change over time, determining whether the 'generational effect' leads to conflict, and potentially failure to agree, or mutual concessions.

\section{Methodology}

The study analyses 186 equality agreements and plans from an administrative database of 18,000 texts lodged with the Ministry of Labour in 2014 and 2015..$^{5}$ From the outset, the project was designed in collaboration with DARES, which holds the database and has expert knowledge on wider patterns of bargaining. In order to define the themes for coding and select sectors, the full database was analysed against the French Labour Force Survey, by company size, gender workforce composition, and type of text (agreements or plans). ${ }^{6}$ Based on existing knowledge of sectors where bargaining was relatively well established or where innovations had been identified in previous studies, a strategy of randomized sampling with stratification by company size and sector was adopted.

Based on preliminary analysis of 10 texts in March 2016, the project team selected 10 sectors for documentary analysis. These 10 sectors account for over half ( 58 per cent) of the total texts in the ministry database: five are femaledominated - financial services (mainly banking and insurance), retail and wholesale sales, foodstuffs and food processing and human health; five are male-dominated - information technology, energy, construction, transport, business services and metalworking; of these, the latter two had been identified as having 'good practice' agreements at sectoral level, focusing on career structures (Ministère du Travail 2015). Apart from energy and finance, the companies represented in these sectors in the database include a majority of smaller- and medium-sized companies (50-299 employees). The gender composition ranges from less than 25 per cent of women in construction to over half in health and finance, although across all sectors it varies between occupational categories.

Within the sample of 186 texts, the gender composition of the workforce ranges from 4 per cent women to 98 per cent; in this respect companies broadly reflect wider sector characteristics. Note that 41.6 per cent of employees in the companies in our sample are women, compared to 48.3 per cent for the same sectors as measured in the 2014 Labour Force Survey. ${ }^{7}$ This difference most likely reflects the more general tendency to negotiate less in female-dominated companies where union representatives are less likely to be present (Castel et al. 2013; Daniel 2017).

In terms of organizational size, our sample follows the wider pattern within the Ministry database, as shown in Table 3, in exhibiting a predominance of smaller and medium-sized companies (71 per cent, compared to 70.9 per cent 
TABLE 3

Text Sample Characteristics: Company Size (Compared to DARES Database)

\begin{tabular}{lcccccc}
\hline & $0-49$ & $50-299$ & $300-399$ & $1,000-4,999$ & $5,000+$ & Total \\
\hline Sample $(n=186)$ & 9 & 123 & 36 & 14 & 4 & 186 \\
$(\%)$ & 4.8 & 66.1 & 19.4 & 7.5 & 2.2 & 100 \\
Ministry database & 867 & 8,450 & 2,566 & 974 & 190 & 13,137 \\
$(\%)$ & 6.6 & 64.3 & 20.2 & 7.4 & 1.4 & 100 \\
\hline
\end{tabular}

for the full database). The sample is thus broadly representative in terms of structural characteristics.

Note that 47.3 per cent of the texts in our sample were unilateral (employer only) plans, compared to 46.9 per cent for the full Ministry database. It was not always possible to identify from the text whether unilateral plans resulted from failure to agree or absence of trade unions, although further research using publicly available sources provided additional information on the former cases, and it was possible to verify using a separate government database whether trade unionists had been elected to workplace representative institutions, as an indicator of union presence. In addition, the Ministry's database of agreements supplied data on other collective agreements signed in the sample companies during the period 2011-2015.

Some sectors showed a more skewed distribution in favour of unilateral plans, in particular construction (60 per cent) and retail and wholesale (58.8 per cent), while only 22.2 per cent of the texts in transport and energy were unilateral plans. The gender composition of the sector seems not to be a primary factor, although it may play a greater role at company level. On the other hand the general bargaining context and dynamics of the sector appears more obviously relevant: those sectors where collective bargaining is more embedded in employer behaviour are also more likely to bargain on gender equality.

Agreements and plans were coded and analysed using MaxQDA software which is particularly suited to textual analysis in mixed methods research (Oliveira et al. 2013). Codes were generated with reference to legal requirements defining data provision and coverage of thematic areas, and the findings of previous national and regional studies (especially Laufer and Silvera 2005; Rabier 2009). Thematic analysis focused on, first, guiding declarations and statements of intent, which establish the sources of reference and define the scope of action on equality; second, the use of statistical indicators to identify the nature and size of gender gaps; and third, the types of action proposed to remedy these gaps. The legislation is prescriptive on all three elements, particularly the second, but in reality a large degree of latitude is observed in the texts. As discussed above, we therefore expected to find a certain amount of formal similarity in form and content (Mias 2014) but also different coverage of these themes both quantitatively and substantively in unilateral (not bargained) plans as opposed to collective agreements, and across sectors. 
The following sections present findings from the textual analysis of the 186 texts, giving examples from the database analysis and also drawing selectively and illustratively on material from case studies carried out in 20 companies, in five of the sectors, carried out in 2016-2017 after completion of the textual analysis. Key characteristics of the case-study companies are summarized in Table 4. They are on the whole larger than the wider sample, and present several other differences due to selection bias (larger companies, those in growing rather than struggling sectors, with higher proportions of highly qualified employees, or which had submitted agreements rather than unilateral plans were significantly more likely to respond to our requests for interviews). The in-depth study nevertheless yields insights not afforded by textual analysis, concerning the process and dynamics of bargaining. The case studies were supplemented with interviews with sectoral-level and nationallevel union federations (CGT and CFDT).

The wider structural factors in turn shape the configurations of gender inequalities in the case-study companies. For example, highly technical sectors tend to be male-dominated and exhibit strong occupational segregation, while low-pay sectors such as retail are highly feminized (Peetz 2017). As noted above, we expect these structural-sectoral features to influence the types of action prioritized in agreements and plans, although there are also key insector differences (most obviously here in manufacturing), which individual examples elucidate. Some sectors are more intensively engaged with collective bargaining than others, and this in turn is related to structure (relative weight of larger firms) as well as economic and other organizational features. Thus, for example, in our smaller case-study sample, fourth-generation agreements are more common in energy and banking, where larger firms with established trade union presence have longer-standing processes of collective bargaining, whereas plans and de novo bargaining processes are more common in the (female-dominated) health and retail sectors, and more generally among smaller companies.

\section{Drivers of gender equality actions}

Legal requirements constitute a toolkit for negotiators, which they can use according to their own interests and resources (Grésy et al. 2014; Rabier 2009). Given the wider context of state-driven collective bargaining, as outlined above, we therefore expected to find a strong common element of legal formalism in the texts in our sample, but also diversity in the way the legal requirements are interpreted, particularly in agreements rather than plans. Only 10 of the texts made no direct reference to legal requirements. Most commonly, texts referred to specific articles of labour law (141 texts, or 76 per cent of the sample). A significant number of texts referred to the 2010 law introducing financial penalties for non-compliance (82 texts, or 44 per cent of the sample). In fact, there was little difference between agreements and plans, although the latter were slightly more likely to refer explicitly to the need 


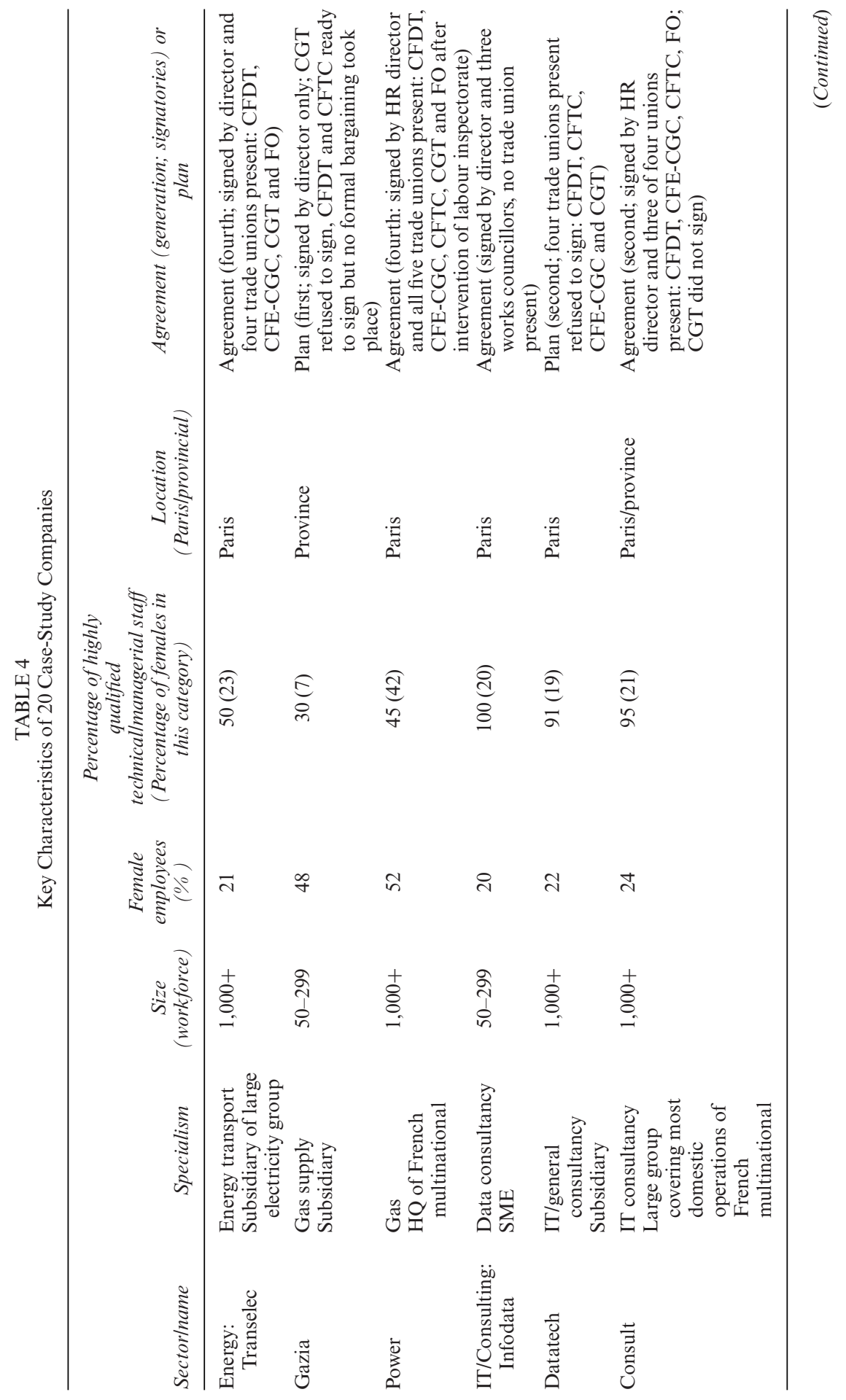




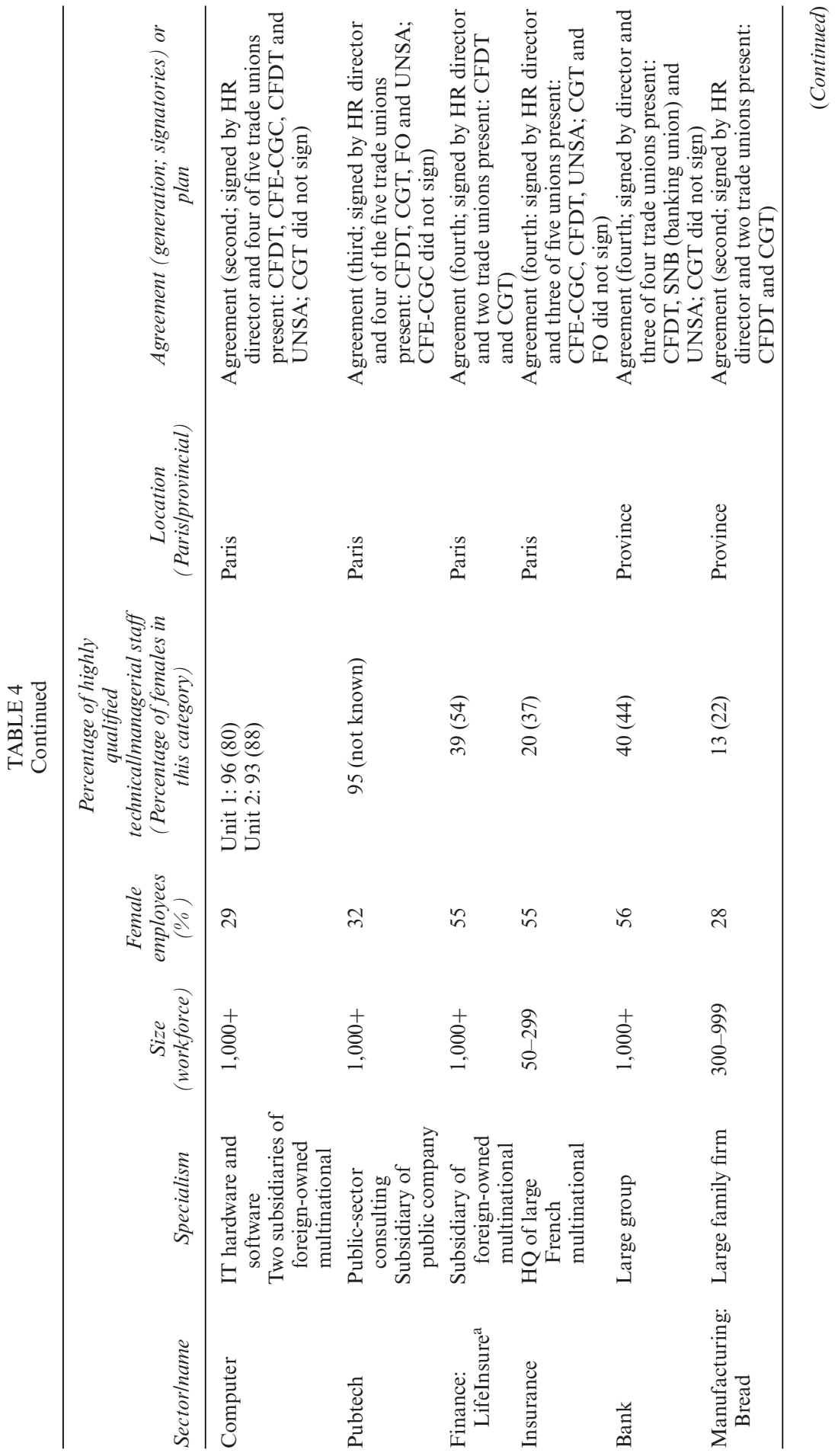




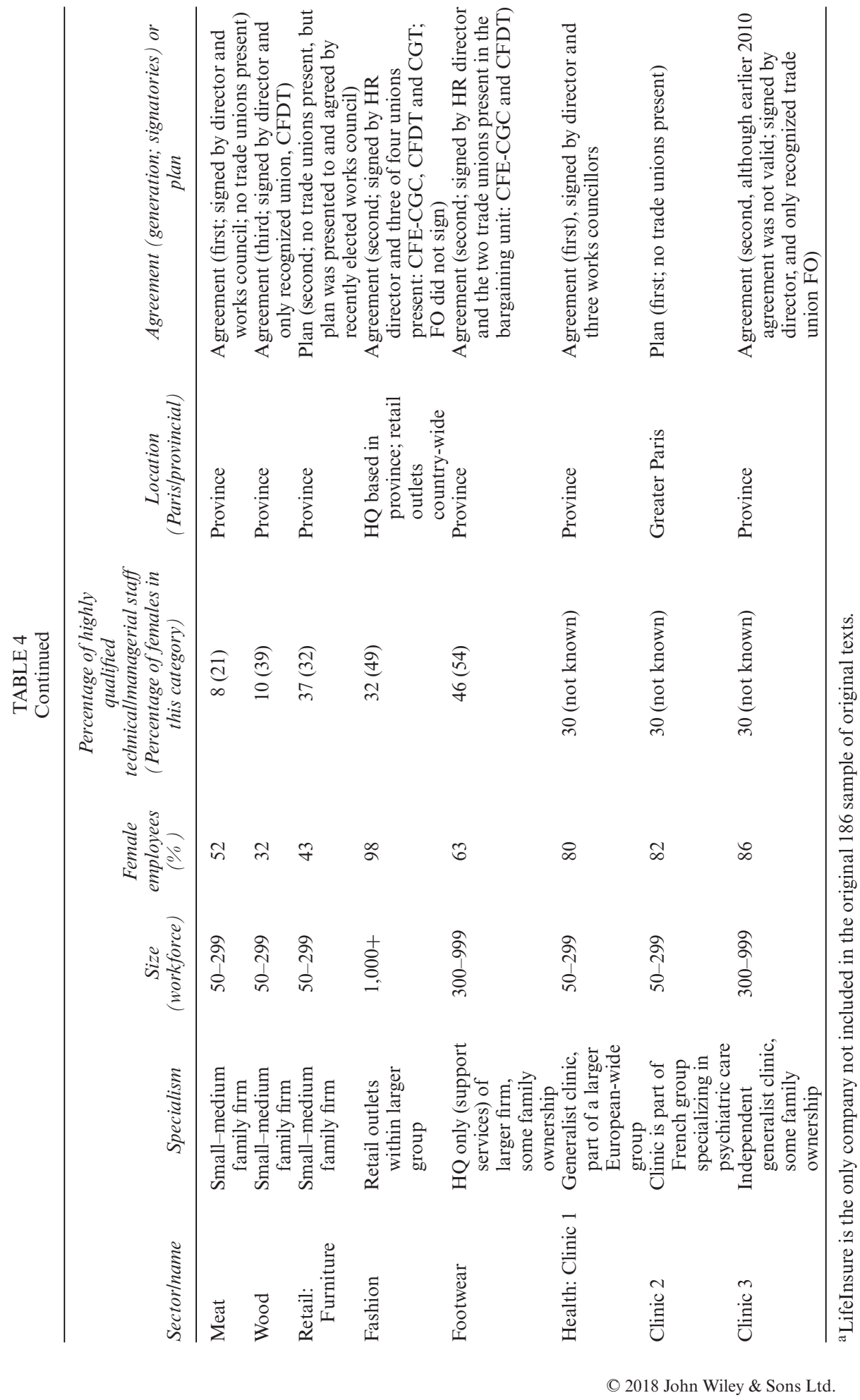


to avoid financial penalties (49 per cent referred to the 2010 law, compared to 40 per cent of agreements). Fewer texts referred to the more recent 2014 law on 'real equality' (46 of the 147 within the sample which were adopted after its introduction). The existence of texts in companies with fewer than 50 employees (see Table 3), which are not subject to the legal requirements, suggests that access to public procurement contracts may also be a factor, as four of these nine companies are in the construction sector.

On the other hand, we found very little reference in the text to sectoral-level agreements, which the law expects to support and guide local level bargaining. Reciprocally, companies are expected to refer to the higher level agreements both to aid data collection and to benchmark their own performance. The law thus relies on coordination of sectoral and local bargaining. In our sample, however, we found only 35 texts (19 per cent of the total) which explicitly mention sectoral agreements. Nevertheless, our thematic analysis identified some discursive similarities within sectors which may reflect a mimetic effect of sectoral texts. This applies more to smaller companies. In some cases (finance and sales), we found texts where companies referred to sectoral agreements rather than the legal requirements, the former improving on the latter in terms of more detailed or focused data provision; elsewhere, in retail, reference to sectoral agreements concerning payment of weekend or evening employment. In the health sector, on the other hand, several texts refer explicitly to the absence of sectoral agreement.

Beyond these legal and macro-institutional factors driving the adoption of equality agreements and plans, the texts give some indication of business approaches to equality policies at local level. The 'business case' for gender equality, in terms of reputational enhancement and improved business performance, has been promoted in France through voluntary charters and good practice accreditation, and was already visible in the first wave of agreements after 2001 (Ackrill et al. 2017; Garner and Recoules 2014; Laufer and Silvera 2005). Around one-third of the sample texts referred to the business case whether as part of the company's self-identification with corporate social responsibility or as explicit reference to performance and attractiveness as an employer of choice. The rhetoric of diversity is particularly associated with multinational companies both foreign-owned (mainly the United States) or domestically headquartered.

Companies which deploy such rhetoric are not demonstrably more engaged in equality auditing or action than others. However, those companies deploying an equality and diversity rhetoric are more likely to emphasize two areas of action: work-life balance measures, and awareness-raising training initiatives (including on gender stereotypes, as encouraged by the 2014 law) where the cost is rarely stated or is recorded as zero to minimal. Instead of quotas and wage compensation or remodelling, as discussed further below, management-driven agendas were more likely to focus on workfamily support and 'softer' awareness-raising initiatives to combat gender stereotypes. In this respect, French businesses' rhetoric of equality and diversity may be seen as guiding a management-led agenda in which trade 
union demands for specific, costed measures make little or no impact. On the other hand, we found very few explicit references to measures being driven by or contingent upon cost-cutting objectives (cf. Riva 2017).

The ambiguity of management-driven 'equality and diversity' plans and agreements is illustrated in a series of interviews with the E\&D manager at BANK. She emphasized her own and management's reluctance to concede measures such as quotas for representation of women at different levels or wage compensation mechanisms to address gender pay gaps ('We don't want to open Pandora's box'). However, she also argued that without the obligation to set quantitative indicators it would be difficult for her to push for action within the company, describing the agreed action plan as 'a secret asset'.

\section{Actions to promote gender equality in agreements and plans}

French law is prescriptive and detailed in its requirements for gendered company information to inform equality bargaining and plans. Detailed analyses of existing gender profiles and pay gaps, and quantitative indicators of progress, are prerequisites for effective action and monitoring (Laufer 2014; Pépin et al. 2008). However, although recent legislation has encouraged more companies to engage in gender workforce auditing, a significant number in our sample (70, or 39 per cent) included no gendered data at all, with agreements even more likely to fail to comply with this requirement than unilateral plans (44 per cent compared to 33 per cent). ${ }^{8}$ In another set of texts, figures are given but without reference to the RSC. Sixty-seven texts (36 per cent of the total) refer at least once to the RSC. Under-specification is true even of several fourth-generation agreements and of larger companies which in theory have more statistical and administrative reporting resources. We speculate here that collective bargaining and relatively long-established reputation in this area may allow companies, particularly larger companies, to direct the process in ways which fit existing objectives and practices, as already noted above for work-family measures. Another explanation which fits the findings of earlier studies (Brochard and Letablier 2013) is that large companies, where unions are more present, seek to avoid specific, quantified commitments which could be used in litigation, in line with the reference by the HR manager cited above to a 'Pandora's box'.

Conversely, companies with 50-299 employees are more likely, within our sample, to refer to the RSC and integrate it into the equality plan. These companies are required to produce a simplified report (RSE) rather than the full RSC. Overall, we observe that although companies complied with the formal requirement to report on at least two or three (depending on company size) specific areas, the statistical information is patchy, not always gendered, and not always verifiable by trade unions or other actors on the ground. Where targets are quantified, this is often done by referring to year-on-year progress rather than absolute figures. 
Of course, the identification of different levels of remuneration between men and women, as expressed as a gender pay gap, does not in itself indicate the existence of inequalities; further analysis of differences in treatment between men and women is needed in order to understand the reasons behind them and any potential inequalities this may reflect. Understanding of such relationships is filtered through existing beliefs, attitudes and positioning of key actors. If collective bargaining is by nature a conflictual process which seeks to resolve antagonistic views (Barbash 1979), equality bargaining therefore presents an additional set of potential conflicts (Chappe and Pochic 2018; Dawson 2014; Laufer 2014). Conflicts over proposed actions are not necessarily apparent in the text of an agreement: as noted above, they may become visible where an external actor has intervened to demand revision of an agreement; they also appear in some cases where a formal statement of non-agreement is appended (Datatech, Gazia), but such statements are not always included. In some cases, conflict also became public when trade unions (notably the CGT) disagreeing with management proposals posted criticism of texts on their website: this happened in four of our case-study companies (Insurance, Computer, Bank and Fashion). In the well-publicized case of another company not included in our sample, the electricity giant EDF (which influences collective bargaining in many other companies due to its extensive network of subsidiaries) lost its Equality and Diversity kitemark due to a formal complaint by the CGT union.

Conflict resulted in a variety of outcomes in the text sample, which are further illustrated in the case studies. Union pluralism in France means that disagreement by one union does not necessarily prevent an agreement from being valid, as long as the unions which sign represent a majority of workers as measured by workplace elections. Thus, for example, in the case of Computer and Consult, the majority CFDT union and others felt able to sign the agreement despite misgivings. In both cases, the resulting agreements are seen as leaders within the sector, as they include sophisticated analysis of pay gaps and identify specific budgets to remedy gender imbalances in pay (Interview with CFDT equality officer, IT Federation, October 2017). In other cases, conflict led to the breakdown of negotiations: this happened at Datatech, resulting in a relatively brief plan which contained a very detailed analysis of gender pay gaps but very little by way of proposed actions to remedy them, and no monitoring or follow-up process. In the case of Gazia, the plan contained a set of intended measures to produce a guide for working parents, and to raise awareness among line managers of parenting constraints of employees, but no monitoring indicators or process. In other words, in both cases, the plans can be seen as having limited effectiveness.

Our documentary analysis indicates that the number of areas covered by the agreement is of less importance than the quality of the data underpinning actions and of the indicators allowing monitoring to take place. As outlined above, larger companies must report on at least four areas (to include pay), and smaller companies two to three. For the minority of companies which produce gender pay gap analysis based on the RSC (27 per cent of the total 
sample), the texts focus primarily on recruitment (16 per cent), training (14 per cent), pay structures (14 per cent) and work-life balance (13 per cent). However, the quality of data varies between these four areas, with considerably less attention paid to pay and work-life balance. Thus, gender pay disparities are predominantly associated with skills and recruitment rather than career progression, pay structures, or the work-family interface. This rather limited view of the causes of pay gaps is also reflected in relatively weak and low-cost remedial measures (awareness-raising and information) in plans, except that work-family measures such as parental leave feature relatively prominently in those texts.

Similarly, we observe a focus on targets for gender balance in higherpaid jobs, with or without specific measures to achieve them (most commonly training and mentoring arrangements), that is, concentration of organizational efforts towards senior management roles. This 'elitist' orientation of equality actions tends to obscure more thorough-going investigation of vertical and horizontal segregation, and may also lead to limited results without more systematic attention to 'pipeline' issues of role allocation and career progression (Jacquemart et al. 2016).

Although pay structures are known to contribute to overall pay disparities in ways which need to be investigated at company level (see Anderson et al. 2001), they are very rarely the focus of analysis of pay gaps in the equality agreements and plans in our sample. Agreements often refer to sectoral pay structures to justify lack of concern or action in this area. Individualized pay systems are commonly explained with reference to performance criteria which are presented as gender-neutral. Very few agreements or plans provide costings for remedial salary adjustments, although where this happens the sums can be substantial, as in the case of Consult (six million euros over five years). Even fewer give a gendered breakdown of bonuses or discretionary payments. In some larger companies, a formal record of disagreement shows that trade unions contested this lack of transparency and tried to push for more detailed gendered comparison of the impact of discretionary payments by paired comparisons by occupation, as for example in the case of Datatech.

The theme of work-life balance has been the subject of an increasing number of agreements and plans (Brochard and Letablier 2017; Fatoux and Silvera 2011; Grésy et al. 2014). Particularly among larger companies, some thematic convergence may reflect the influence of state-supported business initiatives such as the Parenthood, Equality and Diversity charters promoted by leading French multinationals (see Ackrill et al. 2017). A total of 22 texts in the sample referred to equality and diversity charters, although most of these were company policies; four texts referred to the national Parenthood charter, and another four to the Diversity charter, while one mentioned the Diversity kitemark and one the Equality kitemark. However, agreements tend to formalize existing management practices rather than introducing new measures resulting from employee demands mediated by trade unions (Brochard and Letablier 2013). 
As was observed in earlier research (Rabier 2009), in our sample workfamily measures are primarily addressed in company agreements as support for maternity leave and the protection of women's rights; most texts which addressed work-life balance included return-to-work interviews for employees returning from leave. Also under the heading of work-life balance, a predominant theme across different types of text is a general commitment not to hold meetings outside 'regular' working hours, which is difficult to quantify as a monitoring target. In this respect the texts follow a more general trend towards emphasis on measures which stay very close to existing legal requirements. Another example is the common reference, in larger companies, to three days' emergency leave for parents of sick (hospitalized) children, which was about to enter into French law. Nevertheless we also found a small number of innovative agreements on measures for parents exceeding legal requirements and reflecting the content of the Parenting Charter, mostly in (male-dominated, highly qualified) ICT and business services. In such cases, the Charter was referred to explicitly in the text, and even appended in full as in the case of Consult.

Work-family measures proved as likely to spark conflict as pay. In Consult and Fashion, for instance, dissenting trade union demands focused on childcare demands, rights to reduced hours, and day-to-day flexibility and working time autonomy. Such conflicts resulted from relatively developed trade union agendas for change on wage compensation mechanisms to achieve pay equality, leave for working parents, and working time, as discussed further below, and were more likely in companies with three or more competing unions. Measures to support women's careers through mentoring and coaching, or women's networks, proved less controversial, although in some cases they fuelled disagreement where unions argued that proposed indicators of progress were insufficiently specific. For example, at Consult, the CGT refused to sign the agreement on grounds that the original target for promotions had been lowered since the first agreement in 2011, whereas the CFDT team framed their dissatisfaction with this change within the context of broader support for measures to support women's careers: 'On the whole, it's good, because it's that sort of thing that will allow the glass ceiling to be broken over time'.

\section{Trade unions, strategies and resources for equality bargaining}

As previously noted, in our sample, unilateral plans are more likely than collective agreements to include detailed analysis of gender pay gaps and gender profile of the workforce. This finding is counter-intuitive given a wider literature which sees trade unions more engaged with gender equality than employers (see, e.g., Milner and Gregory 2014). A crucial factor here could be the resources provided by private consultants or public advisors. The use of private consultants to conduct gender pay and workforce analysis is widespread and was found in most of our case study companies, including in 
those submitting plans rather than agreements, although it may not always have been evident in the texts themselves. Larger companies were more likely to have sought external expertise although three of our six small case-study companies based their texts on consultancy analysis (Gazia, Infodata and Insurance), while a fourth (Wood) had given the task to an intern employed especially for that purpose; on the other hand, the private health sector seems to have done relatively little pay analysis and our case-study clinics had not employed consultants.

This observation suggests that trade unions may be a significant actor in equality bargaining but that their presence may not be a prerequisite for action, in a context where the state provides incentives to bargain and supporting resources are widely available. However, the provision of detailed diagnostic data is only part of the basis for effective action. British research shows that in order for equality agreements to be more than 'empty shells', there need to be actors who are mobilized to push for action (Hoque and Noon 2004). Collective agreements were more likely than plans to specify quantitative targets and indicators of progress, and to identify mechanisms for monitoring and follow-up. This is particularly true as plans, compared to agreements overall, were of more recent origin (first or second generation), suggesting that they had been motivated by the introduction of financial penalties. Plans also have a shorter lifespan, of one year compared to three years for a collective agreement.

Trade unions themselves have been criticized in the past for giving insufficient attention to gender equality (Milner and Gregory 2014). However, the two largest confederations (CFDT and CGT), in particular, have striven in recent years to prioritize gender and have feminized their leadership structures using quotas. Nevertheless, ambivalences remain, reflecting different confederal strategies regarding collective bargaining in general (see Gumbrell-McCormick and Hyman 2013), and equality bargaining more specifically, because trade unions are often in a weak position in relation to employers at company level and feel ill-equipped to complex issues affecting different groups of employees differently (Brochard and Letablier 2017).

Agreements signed by non-union workplace representatives, usually works councils, are relatively rare (nine cases in our sample). Along with unilateral plans which include mention of being presented to works councils for monitoring, such texts are less likely to result in effective action because the representatives have less independence from management and less access to external resources than trade unions. Nevertheless, this does not mean that the plans are completely ineffective, because they include at least the possibility, albeit limited, of employee access to information.

The CGT while strongly supporting equality bargaining argues that the law requires only that employers engage in bargaining, or submit plans, and does not make any stipulations about the outcome other than reporting key data. Without tougher sanctions aimed at the content of texts, bargaining often results in 'a purely formal exercise without any substance' (CGT 2016: 70). Local CGT bargaining teams are encouraged to situate equality bargaining 
within a wider structural analysis and to reject texts which do not address key demands, particularly around working time. In our sample of 186 texts, the CGT was the union, the most likely to reject agreements (refusal to sign in eight cases, compared to four for FO and three for CFE-CGC, CFDT).

In comparison with the CGT, the CFDT tends to sign more agreements in general, including on gender equality, and this tendency appears in our sample of texts and in our case studies. Fifty-eight of the texts were signed by the CFDT (41 by CFE-CGC, 33 by CGT, 31 by FO, 26 by CFTC and 14 by others such as UNSA). However, the CFDT too has started to question the utility of signing 'paper' agreements. Equality officers at confederal and federal levels told us that they ask local bargaining teams to submit texts to them before signing, and advise on whether or not to sign, based on their knowledge of what constitutes 'good' practice across the sector. The federal level thus constitutes a resource for local unions, as we found in the case of Power and Consult where the federal officer took part in meetings held by the local CFDT team to consult with members and elected representatives throughout the bargaining process.

Other resources deployed local unions include the use of external consultants, as in the case of Computer and Consult. In two cases in our sample (in line with confederal emphasis on enforcement), both in the energy sector, the local CGT union called in the labour inspectorate which in both cases called the parties back to the table, deeming agreements incomplete and therefore non-compliant because of insufficiently detail on pay and promotions. These were the only such case we uncovered and they reflect both the pioneering nature of the early energy agreements (and therefore the importance from an enforcement viewpoint of upholding the quality of the text) and the strength of the larger unions in the sector.

Overall, our analysis confirms that trade unions often find themselves in a weak bargaining position on gender equality. In several cases, unions were found to 'accompany' local bargaining with little opportunity to formulate independent agendas or influence proposed texts; our case studies suggest that this may happen particularly in companies or establishments with only one or two unions. In Footwear, for example, the CFDT and CFE-CGC teams had only recently been recognized in the bargaining unit and were reluctant to jeopardize gains made in annual wage bargaining (mainly an agreement to include periods of maternity leave in calculating bonuses and pensions) by rejecting the equality agreement, even though they saw it as unsatisfactory. In Clinic 3, the FO union similarly spoke of not wishing to disrupt a generally benign paternalistic bargaining culture, and expressed a preference for informal negotiation of individual requests for working time flexibility.

\section{Conclusion}

This analysis of the 'fourth wave' of gender equality bargaining in France, following the introduction of financial penalties for non-compliance in 2010 , 
has highlighted its macro-institutional specificity, and its strengths and weaknesses. Our findings confirm our expectation, formulated on the basis of earlier research, that a large degree of variation in practice reflects sectoral and local bargaining cultures and dynamics. Generational effects, whereby successive rounds of bargaining developed existing agreements signed after 2004, were not uniform but rather depended on local bargaining practices and also the economic situation of the company, with some organizations seeking to reduce commitments made in earlier texts in the context of economic downturn, others using quantitative indicators to monitor outcomes and build on previous actions, including in at least two cases substantial wage compensation payments to female employees.

Although successive tightening of legal requirements (coupled with threat of enforcement and financial penalties) has resulted in increasing levels of formal compliance, a large degree of latitude in practice means that most companies are still eluding in-depth, multi-stakeholder analyses of local practices leading potentially to an understanding of gender pay disparities. Actions are most likely to be those which are relatively low-cost and targets are often broad enough to enable box-ticking practices. Discourses of equality, diversity and parity (equal representation of men and women in decision making and representational posts and bodies) permeate the texts. However, they are often used interchangeably, without precise definition, and without specific reference to contextualized indicators or actions.

This does not mean that local actors such as trade unions are always passive or disempowered; on the contrary, our sample includes a number of cases where the 'generational effect' provides opportunities for 'learning by doing', or sparks conflictual processes where bargaining parties can use the resources available to them (such as appeals to external experts or mobilization of reputational pressures).

Our analysis raises a number of questions about the efficacy of statemanaged bargaining, in the case of actions to promote gender equality. The first concerns effective enforcement. It has been suggested that the gap between formal and substantive compliance undermines the case for sanctions (financial penalties) (Naboulet 2011). On the contrary, we argue based on our findings that although penalties are by themselves insufficient to bring about behavioural change, they are nevertheless an essential lever for change. Compliance pressures can empower local change actors, but further resources are also required.

The enforcement machinery itself is one such resource. We found, for example, in the case of Clinic 3, that the local labour inspectorate worked with the organization to ensure that the text of an agreement met legal requirements, using a succession of formal warnings. In two examples of larger companies, as discussed above, the intervention of labour inspectors pushed negotiators back to the table to agree more detailed proposals for action. Developing a more responsive approach to substantive as well as formal compliance would, however, require substantial investment in the regional labour inspectorates, which is politically difficult under austerity 
(the number of labour inspectors has decreased by 20 per cent since 2008).

Our analysis found that external expertise plays an important part in supporting companies to construct the informational base for equality actions. These can be public agencies (regional authorities and agencies specializing in working conditions and health and safety) as well as private consultants. Financial support for external expertise and/or in-house training, as well as investment in nationwide networks of support agencies, would therefore constitute a 'smart' way of complementing legal sanctions with responsive incentives.

Our analysis raises questions about the articulation of sectoral and local (company and workplace levels). It suggests that local bargaining can be substantially strengthened by informational resources provided at sectoral level, such as databases of agreements, guides and toolkits for negotiators, and direct advice to local bargaining teams. Legislators wishing to promote decentralization should therefore also pay attention to incentives for sectorallevel initiatives.

However, without strong state impulsion and 'the shadow of hierarchy', 'bargained equality' is likely to have uneven outcomes. The 2017 labour law reforms accelerated the longer-term trends towards 'organized decentralization' (Baccaro and Howell 2017). French trade unions and many labour lawyers argue that the shift from law to bargaining will weaken employer duties and risks downgrading gender equality in a context where it is already marginal in comparison with other priorities (Binet 2017; Miné 2016). Our analysis gives weight to those fears and confirms that state-level sanctions and obligations are a crucial driving factor.

Final version accepted on 6 September 2018

\section{Notes}

1. Unpublished Ministry of Labour figures, March 2016, supplied to the research team.

2. Those including gender equality within other subjects deal primarily with wages (wage-setting remaining the main function of sectoral-level bargaining), followed by training, diversity management, job classifications, age management and working time (part-time work) (Ministère du Travail 2015: 348-89).

3. These figures should be considered in relation to the structure of the French economy, where over half $(53 \%)$ of all companies are micro-enterprises with fewer than 50 employees. It is difficult to provide an exact estimate of the proportion of companies in each of the three groupings as the thresholds do not correspond to those in official measurements of company size, but by way of broad comparison: around $28 \%$ of companies have between 50 and 249 employees, and $8 \%$ have between 250 and 499 and just under $11 \%$ have over 500 employees. Figures are from 2011 (Lemasson 2014).

4. The last of these indicators was included in 2014 because of pressure from the largest trade union confederation, CGT, through lobbying and labour courts In 
companies with 50-299 employees, a report (Rapport de situation économique or RSE) covering company information, pay structure and employment planning must provide a gender breakdown of workforce composition, type of contract, working time, mean and median pay gaps.

5. Since the introduction of financial sanctions, there is greater oversight by the Ministry of equality plans and agreements; however initial cleaning of the wider database was necessary as some documents are empty or wrongly filed.

6. French legal requirements to bargain do not specify the bargaining unit, which can include an entire group or cover just one unit within it, but the text must specify which employees are covered. In practice, texts did not always specify which employees were covered within the bargaining unit and further verification was required by researchers.

7. The Ministry does not monitor the database for gender workforce composition, so we compared against the Labour Force Survey; relevant data were missing from 42 texts in our sample.

8. It is not always evident where labour inspectors have rejected agreements as incomplete; follow-up fieldwork suggests this may apply to a significant proportion of plans registered in the database.

\section{References}

Ackrill, R., Caven, V. and Alaktif, J. (2017). "Black boxes' and 'fracture points': the regulation of gender equality in the UK and French construction industries'. International Journal of Human Resource Management, 28 (21): 3027-46.

Amossé, T., Bloch-London, C. and Wolf, L. (2008). Les Relations Sociales en Entreprise. Un Portrait à Partir des Enquêtes REPONSE. Paris: La Découverte.

Anderson, T., Forth, A., Metcalf, H. and Kirby, S. (2001). The Gender Pay Gap. London: Department for Education and Employment.

Baccaro, L. and Howell, C. (2017). Trajectories of Neoliberalism. Cambridge: Cambridge University Press.

Barbash, J. (1979). 'Collective bargaining and the theory of conflict'. Relations Industrielles/Industrial Relations, 34 (4): 646-59.

Bechter, B. and Brandl, B. (2014). 'Developments in European industrial relations'. In Directorate-General for Employment, Industrial Relations in Europe in 2014. Brussels: European Commission, pp. 28-36.

Bender, A.-F., Klarsfeld, A. and Laufer, J. (2010). 'Equality and diversity in the French context'. In A. Klarsfeld (ed.), International Handbook on Diversity Management at Work: Country Perspectives on Diversity and Equal Treatment. Cheltenham: Edward Elgar, pp. 83-108.

Bereni, L. (2015). La Bataille de la Parité. Mobilisations pour la Féminisation du Pouvoir. Paris: Economica.

Berg, P. and Piszczek, M. (2014). 'The limits of equality bargaining in the USA'. Journal of Industrial Relations, 56 (2): 170-9.

Binet, S. (2017). 'Les inégalités ne sont pas une fatalité: le point de vue de la CGT'. Travail, Genre et Sociétés, 37 (1): 167-70.

Blau, F. D. (2012). Gender, Inequality and Wages. Oxford: Oxford University Press.

Bohnet, I. (2016). What Works. Cambridge, MA: Harvard University Press. 
Bosch, G. (2015). 'Shrinking collective bargaining coverage, increasing income inequality: a study of five ELI countries'. International Labour Review, 154 (1): 57 66.

Brochard, D. and Letablier, M. (2013). Les Dispositifs d'Entreprise en Direction des Familles. Report CFDT-IRES, Paris.

- and - (2017). 'Trade union involvement in work-family life balance': lessons from France'. Work, Employment \& Society, 31 (4): 657-74.

Brown, W. A. (2009). The Evolution of the Modern Workplace. Cambridge: Cambridge University Press.

Bruno, I., Didier, E. and Prévieux, J. (2014). Stat-Activisme. Comment Lutter Avec les Nombres. Paris: La Découverte.

Castel, N., Delahaie, N. and Petit, H. (2013). 'L'articulation des négociations de branche et d'entreprise dans la détermination des salaires'. Travail et Emploi, 134: $21-40$.

Chappe, V.-A. and Pochic, S. (2018). "“No, this gap is not significant” Battles around equal pay in French private companies'. Gender, Work \& Organization, 24 (1): 1-18.

Chicha, M.-T. (2006). A Comparative Analysis of Promoting Pay Equity: Models and Impacts. Geneva: International Labour Organisation.

Combrexelle, J.-D. (2015). La Négociation Collective, le Travail et l'emploi. Paris: Report to Prime Minister.

Confédération Générale du Travail (CGT). (2016). Réussir l'égalité Femmes-Hommes dans la CGT! Montreuil: CGT (Commission des Femmes et de la Mixité).

Conley, H. and Page, M. (2018). 'The good, the not so good and the ugly: gender equality, equal pay and austerity in English local government'. Work, Employment and Society, 32 (4): 789-805.

Daniel, C. (2017). 'La négociation collective d'entreprise en 2015. Stabilité de la part des entreprises qui négocient'. DARES Résultats, 66: 1-9.

Dawson, T. (2014). 'Collective bargaining and the gender pay gap in the printing industry'. Gender, Work \& Organization, 21 (5): 381-94.

Deakin, S., Fraser-Butlin, S., Polanska, A. and McLaughlin, C. (2015). 'Are litigation and collective bargaining complements or substitutes for achieving gender equality? A study of the British Equal Pay Act'. Cambridge Journal of Economics, 39 (2): 381403.

Dickens, L. (2000). 'Collective bargaining and the promotion of gender equality at work: opportunities and challenges for trade unions'. Transfer, 6 (2): 193-208.

Dobbin, F. and Kalev, A. (2016). 'Why diversity programs fail'. Harvard Business Review, July-August.

Dunez, A. and Graff, D. (2013). L'égalité Professionnelle Femmes-Hommes en Rhône Alpes: Accords, Plans D'actions et Négociations Annuelles Obligatoires. Lyon: DIRECCTE - Service ESE.

Edelman, L. B., Fuller, S. R. and Mara-Drita, I. (2001). 'Diversity rhetoric and the managerialization of law'. American Journal of Sociology, 106 (6): 1589-641.

Fatoux, F. and Silvera, R. (2011). La Place des Hommes Dans les Accords d'Entreprises sur l'Egalité Professionnelle. Paris: Observatoire de la Responsabilité Sociétale des Entreprises.

Garner, H. and Recoules, M. (2014). Égalité, diversité, discrimination. Étude de 80 accords d'entreprise sur la diversité. Document d'études no. 182. Paris: DARES.

Giraud, B. and Ponge, R. (2016). 'Des négociations entravées'. La Nouvelle Revue du Travail, 8: 38-50. 
Grésy, B. and Becker, M. (2017). Guide Pour la Prise en Compte de l'égalité entre les femmes et les Hommes Dans les Systèmes de Classification. Paris: Conseil Supérieur de l'Égalité Professionnelle entre les Femmes et les Hommes.

_ - _ and Derrien-Cortes, C. (2014). La Négociation de l'égalité dans les Entreprises de 50 à 300 Salariés en 2012 et 2013. Report no. 2014-002. Paris: Conseil Supérieur de l'Égalité Professionnelle entre les Femmes et les Hommes.

Greulich, A., Letablier, M.-T., Brochard, D. and Auberger, M. N. (2013). Les Dispositifs des Entreprises en Direction des Familles. Paris: Université Paris $1 \mathrm{La}$ Sorbonne.

Grimshaw, T., Bosch, G. and Rubery, J. (2014). 'Minimum wages and collective bargaining: what types of pay bargaining can foster positive pay equity outcomes?' British Journal of Industrial Relations, 52 (3): 470-98.

Groux, G. (2005). 'L'action publique négociée. Un nouveau mode de régulation?' Négociations, 3: 57-70.

Gumbrell-McCormick, R. and Hyman, R. (2013). Trade Unions in Western Europe: Hard Times, Hard Choices. Oxford: Oxford University Press.

Hoque, K. and Noon, M. (2004). 'Equal opportunities policy and practice in Britain: evaluating the "empty shell" hypothesis'. Work, Employment and Society, 18 (3): 481-506.

Jacquemart, A., Le Mancq, F. and Pochic, S. (2016). 'Femmes hautes fonctionnaires en France, l'avènement d'une égalité élitiste'. Travail, Genre et Sociétés, 35: 27-45.

Kirton, G. (2011). 'Gender, equality, diversity, and a new industrial relations paradigm?' In A. Wilkinson and K. Townsend (eds.), The Future of Employment Relations. Basingstoke: Palgrave, pp. 30-46.

Laufer, J. (2014). L'égalité Professionnelle Entre les Femmes et les Hommes. Paris: La Découverte.

—_ and Silvera, R. (2005). Accords sur l'égalité Professionnelle Suite à la loi du 9 mai 2001: Premiers Eléments d'Analyse. Montreuil: Timetis/Emergences.

Lemasson, J. (2014). 'Les catégories d'entreprise en France: de la microentreprise à la grande entreprise'. Insee Focus, no. 5, 1-4.

Lemière, S. and Silvera, R. (2010). 'Un salaire égal pour un travail de valeur comparable entre les femmes et les hommes. Résultats de comparaisons d'emplois'. La Revue de l'IRES, 3: 63-92.

Mias, A. (2014). 'Entre complexification et simplification du travail de négociation. L'ambivalence des pratiques de connaissance en entreprise'. Nouvelle Revue de Psychosociologie, 18 (2): 41-53.

—_, Guillaume, C., Denis, J.-M. and Bouffartigue, P. (2016). 'Vers un dialogue social administré?' La Nouvelle Revue du Travail, 8: 1-12.

Milner, S. and Gregory, A. (2014). 'Gender equality bargaining in France and the UK: an uphill struggle?' Journal of Industrial Relations, 56 (2): 256-63.

Miné, M. (2016). Droit des Discriminations dans l'emploi et le Travail. Paris: Larcier.

Ministère du Travail, de l'Emploi et de la Santé (Ministère du Travail) (2014). La Négociation Collective en 2013. Paris: DARES.

- (2015). La Négociation Collective en 2014. Paris: DARES.

Munoz, D. (2013). 'Analyse d'une sélection d'accords et de plans d'action d'entreprise signés en Provence Alpes- Côte d'Azur'. Théma, 36: 1-8.

Naboulet, A. (2011). Les obligations et incitations portant sur la négociation collective. Note d'Analyse no. 240, Centre d'Analyse Stratégique, 12.

Oliveira, M., Bitencourt, C., Teixeira, E. and Santos, A. C. (2013). 'Thematic Content Analysis: Is There a Difference in the Support Provided by the MaxQDA and 
NVivo Software Packages?' In A. Mesquita (ed.), Proceedings of the 13th European Conference on Research Methodology for Businesss and Management Studies. Guimares, Portugal: University of Minho, pp. 304-10.

Organization for Economic Cooperation and Development (OECD). (2016). Gender Pay Gap Statistics. Paris: OECD. Available at: https://data.oecd.org/earnwage/ gender-wage-gap.htm

Peetz, D. (2017). Regulation distance, labor segmentation, and gender gaps. In D. Peetz and G. Murray (eds.), Women, Labor Segmentation, and Regulation: Varieties of Gender Gaps. London: Palgrave Macmillan, pp. 3-22.

Pépin, M., Maufroy, M. and Flottes, A. (2008). La mise en oeuvre des Accords d'égalité Professionnelle. Analyse de Huit Démarches d'entreprise. Paris: DARES.

Pignoni, M. T. (2016). 'La syndicalisation en France. Des salariés deux fois plus syndiqués dans la fonction publique'. DARES Analyses, 25: 1-10.

(2017). 'De l'adhérent au responsable syndical. Quelles évolutions dans l'engagement des salariés syndiqués?' DARES Analyses, 15: 1-8.

Qin, J., Muenjohn, N. and Chhetri, P. (2014). 'A review of diversity conceptualizations: variety, trends, and a framework'. Human Resource Development Review, 13 (2): 133 57.

Rabier, M. (2009). 'Analyse du contenu des accords d'entreprise portant sur l'égalité professionnelle entre les femmes et les hommes signés depuis la loi du 23 mars 2006'. In Ministère du Travail, La Négociation Collective en 2008, pp. 423-60.

Rehfeldt, U. and Vincent, C. (2018). 'The decentralisation of collective bargaining in France: an escalating process'. In S. Leonard and R. Pedersini (eds.), Multi-employer Bargaining under Pressure: Decentralisation Trends in Five European Countries. Brussels: European Trade Union Institute, pp. 151-84.

Riva, E. (2017). 'Background and rationale of collective bargaining around workfamily issues in Italy: the duality of the business case argument'. Employee Relations, 39 (4): 459-74.

Rubery, J. and Smith, M. (2015). 'The 40-year pursuit of equal pay: a case of constantly moving goalposts'. Cambridge Journal of Economics, 39 (2): 319-43.

Smith, M., Srinivasan, P. and Zhuk, K. (2012). 'Women in top management in France: a time of change?' In C. Fagan, M. C. González Menéndez and S. Gómez Ansón (eds.), Women on Corporate Boards and in Top Management: European Trends and Policy. Basingstoke: Palgrave, pp. 150-69.

Voss, E., Schöneberg, K. and Rodriguez Contreras, R. (2015). Collective Bargaining in Europe in the 21st Century. Dublin: Eurofound.

Williamson, S. and Baird, M. (2014). 'Gender equality bargaining: developing theory and practice'. Journal of Industrial Relations, 56 (2): 155-69. 